\title{
Investigation of Water Quality and its Quotient Factor in Thiruppalai Village, Madurai, India.
}

\author{
Dr.P.S.Navaraj ${ }^{1}$ and S.Krishnammal ${ }^{2}$ \\ Associate Professor \\ ${ }^{I}$ Department of Zoology, Yadava College, Madurai. \\ ${ }^{2}$ Department of Chemistry, EMG Yadava Women's College, Madurai
}

\begin{abstract}
The major challenge in rural areas of Madurai district is to gain access to clean and potable water and these results in water borne diseases. The objective of this study was to assess physical, chemical, biochemical and microbial profile of water in 12 hand - dug wells in a rural area, Thiruppalai of Madurai District. Probing of water quality in seasonal variations and proximity to pollution sources (municipal waste dumps and defecation sites) was done. Water quality parameters were determined following the standard procedures mentioned in APHA. All parameters were detected up to $300 \mathrm{~m}$ from pollution sources. Almost all water parameters have shown high increase during the rainy season over the dry periods, pointing to infiltrations from storm water. Significantly, coliform, $\mathrm{Pb}, \mathrm{NO} 3$ and $\mathrm{Cd}$ level have exceeded the recommended values for potable water. The distance from the pollution sources has more pronounced on fecal and total coliform counts and thus values decreased with increasing distance from pollutant sites. The qualities of the drinking water sources in public places were therefore not compatible for human consumption without proper treatment. Regular monitoring of groundwater quality, enactment of healthy waste disposal practices and strict enforcement of modern techniques in water management is highly recommended
\end{abstract}

\section{Introduction}

Thiruppalai, a remote village of Madurai District, is one of the water starved areas of Tamilnadu. Normally, groundwater resources are under severe threat from either by pollution or by low level of hygiene practiced (Adesuyin et al 1983; Sangodoyin and Agbawhe 1992) and this is observed in Tiruppalai village. The health and well being of any individual is fully dependant on environmental health (Cruise and Miller, 1994). Hence, as and when environment is spoiled by the addition of toxic materials or infiltration of bacteria then it shall create a variety of health problems (Ugboaja, 2004; Efe et al 2005) such as water - borne diseases (Agbu et al 1988; Sangodiyin 1993; Alabe 2002; USPA 2002) and this status is also observed in the study place.

Hitherto, physical, chemical, biochemical and microbial profile of water in hand-dug wells located in the residential areas, close to solid waste dumpsites and open defecation sites in Thiruppalai were assessed. An evaluation of the effect of seasons and proximity to pollution sources (municipal waste dumps and defecation sites) on water quality was done. Subsequently, using the data, the water quality quotient factor was calculated. This new finding shall provide ample support for the water managers of this village.

\subsection{Study Area}

\section{Materials and Methods}

The study area Thiruppalai village in Madurai district of Tamilnadu has major season's via., wet or rainy season begins in October and ends in December and the dry season begins in March and ends in May.

\subsection{Sample Collection}

Water samples were collected from 12 hand- dug wells, whose depths varied from three to $12 \mathrm{~m}$, located in the vicinities of rural solid-waste dumpsites, open - air defecation sites, twice a month for a period of two months each in dry and wet season. Water quality parameters such as $\mathrm{pH}$, temperature, conductivity, total solids (TS), total suspended solids (TSS), total dissolved solids (TDS), turbidity, nitrate (NO3-), sulphate (SO 42-), phosphate (PO43-), copper ( $\mathrm{Cu}$ ), lead ( $\mathrm{Pb}$ ), cadmium (Cd), dissolved oxygen (DO), chemical oxygen demand (COD), biochemical oxygen demand (BOD), fecal coliform (FC) and total coliform (TC) counts were computed using the standard procedures of APHA (1980).

\subsection{Water Samples Quality Analysis:}

All plastics and glass wares used for sample collection were pre-washed with detergent water solution, rinsed with tap water and soaked for $48 \mathrm{~h}$ in $50 \% \mathrm{HNO}$, then rinsed thoroughly with distilled-deionized water. Water samples used for estimating the of physical properties and chemical properties via., $\mathrm{SO}_{4}, \mathrm{NO}_{3}$, metals and DO, COD, BOD and $\mathrm{PO}_{4}$ were collected in plastic bottles and specialized glasswares respectively. 
Investigation of Water Quality and its Quotient Factor in Thiruppalai Village, Madurai, India.

Subsequently, all parameters of water sample were tested following the standard procedures (APHA, 1980). All containers for bacteriological analysis were sterilized in an autoclave at $121^{\circ} \mathrm{C}$ for 15 minutes.

Data Analysis

Analysis of variance (ANOVA) was done to exhibit the significant variations between seasons, places and interaction between seasons and places.

\section{Results}

The Values for the water quality parameters are presented in Tables 1-4. The high values of TSS, $\mathrm{PO}_{4}$, BOD and COD are found in the unprotected wells. Likewise, these values are varied with seasonal change and distance from pollution source. The concentrations of Electrical conductivity, BOD, COD, TDS, $\mathrm{Cu}, \mathrm{Pb}$, fecal coliform and total coliform has increased more in rainy season when compare with dry season (Tables 1-4 and Figs. $1 \& 2$ ).

Table 1: Mean values for the water quality parameters of wells located close to waste dumpsite in dry season.

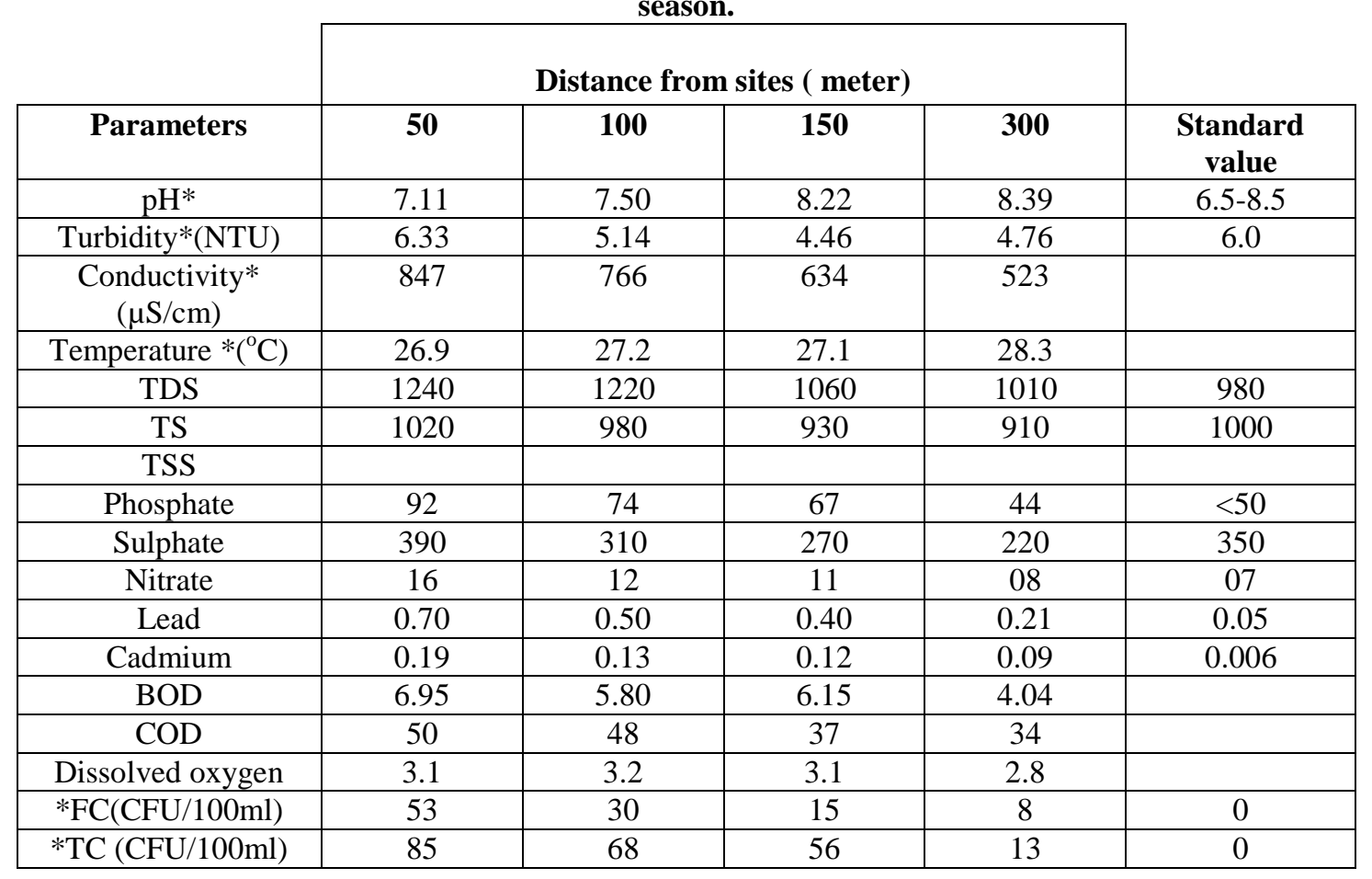

Except * all are in ppm.

Table 2: Mean values for the water quality parameters of wells located close to waste dumpsite in wet season.

\begin{tabular}{|c|c|c|c|c|c|}
\hline \multirow[b]{3}{*}{ Parameters } & \multicolumn{4}{|c|}{ season. } & \multirow{3}{*}{$\begin{array}{l}\text { Standard } \\
\text { value }\end{array}$} \\
\hline & \multicolumn{4}{|c|}{ Distance from pollution sites ( meter) } & \\
\hline & $\mathbf{5 0}$ & 100 & 150 & 300 & \\
\hline $\mathrm{Ph}^{*}$ & 7.01 & 7.10 & 7.12 & 7.29 & $6.5-8.5$ \\
\hline Turbidity *(NTU) & 6.33 & 5.84 & 4.26 & 3.86 & 5.0 \\
\hline $\begin{array}{l}\text { Conductivity* } \\
(\mu \mathrm{S} / \mathrm{cm})\end{array}$ & 890 & 804 & 720 & 420 & \\
\hline Temperature $*\left({ }^{\circ} \mathrm{C}\right)$ & 27.2 & 27.5 & 27.7 & 26.1 & \\
\hline TDS & 1420 & 1270 & 1160 & 1020 & 1000 \\
\hline TS & 980 & 790 & 720 & 690 & 1000 \\
\hline \multicolumn{6}{|l|}{ TSS } \\
\hline Phosphate & 64 & 50 & 42 & 32 & $<50$ \\
\hline Sulphate & 520 & 500 & 470 & 410 & 400 \\
\hline Nitrate & 20 & 16 & 14 & 11 & 10 \\
\hline Lead & 0.69 & 0.52 & 0.41 & 0.38 & 0.05 \\
\hline Cadmium & 0.5 & 0.4 & 0.4 & 0.1 & 0.005 \\
\hline
\end{tabular}


Investigation of Water Quality and its Quotient Factor in Thiruppalai Village, Madurai, India.

\begin{tabular}{|l|l|l|l|l|l|}
\hline BOD & 7.25 & 6.70 & 5.85 & 4.30 & \\
\hline COD & 50 & 41 & 38 & 32 & \\
\hline Dissolved oxygen & 3.6 & 3.2 & 3.1 & 3.0 & \\
\hline FC(CFU/100ml) & 42 & 30 & 16 & 10 & 0 \\
\hline TC $($ CFU/100ml) & 110 & 68 & 56 & 13 & 0 \\
\hline
\end{tabular}

( All values are expressed in ppm except *)

Table 3: Mean values for the water quality parameters of wells located close to defecation sites in dry season.

\begin{tabular}{|c|c|c|c|c|c|}
\hline \multirow[b]{2}{*}{ Parameters } & \multicolumn{4}{|c|}{ Distance from sites ( meter) } & \multirow[b]{2}{*}{$\begin{array}{l}\text { Standard } \\
\text { value }\end{array}$} \\
\hline & $\mathbf{5 0}$ & 100 & 150 & 300 & \\
\hline$*_{\mathrm{pH}}$ & 7.31 & 7.60 & 8.32 & 8.49 & $6.5-8.5$ \\
\hline *Turbidity (NTU) & 6.5 & 4.8 & 4.2 & 3.86 & 5.0 \\
\hline $\begin{array}{l}\text { *Conductivity } \\
(\mu \mathrm{S} / \mathrm{cm})\end{array}$ & 657 & 616 & 585 & 401 & \\
\hline *Temperature $\left({ }^{\circ} \mathrm{C}\right)$ & 27.2 & 27.1 & 27.7 & 26.8 & \\
\hline TDS & 1240 & 1190 & 1140 & 1080 & 1000 \\
\hline TS & 1090 & 1020 & 950 & 910 & 1000 \\
\hline \multicolumn{6}{|l|}{ TSS } \\
\hline Phosphate & 72 & 66 & 60 & 54 & $<50$ \\
\hline Sulphate & 360 & 340 & 300 & 240 & 400 \\
\hline Nitrate & 18 & 14 & 13 & 11 & 10 \\
\hline Lead & 0.70 & 0.55 & 0.38 & 0.24 & 0.05 \\
\hline Cadmium & 0.24 & 0.20 & 0.16 & 0.10 & 0.005 \\
\hline BOD & 6.9 & 6.1 & 5.8 & 5.3 & \\
\hline COD & 45 & 38 & 35 & 30 & \\
\hline Dissolved oxygen & 3.8 & 3.4 & 3.2 & 4.1 & \\
\hline$*^{*} \mathrm{FC}(\mathrm{CFU} / 100 \mathrm{ml})$ & 72 & 58 & 42 & 31 & 0 \\
\hline$* \mathrm{TC}(\mathrm{CFU} / 100 \mathrm{ml})$ & 120 & 100 & 90 & 56 & 0 \\
\hline
\end{tabular}

( All values are expressed in ppm except *)

Table 4: Mean values for the water quality parameters of wells located close to defecation sites in wet season.

\begin{tabular}{|c|c|c|c|c|c|}
\hline \multirow[b]{2}{*}{ Parameters } & \multicolumn{4}{|c|}{ Distance from sites ( meter) } & \multirow[b]{2}{*}{$\begin{array}{l}\text { Standard } \\
\text { value }\end{array}$} \\
\hline & 50 & 100 & 150 & 300 & \\
\hline$* \mathrm{pH}$ & 5.19 & 6.02 & 6.08 & 6.49 & $6.5-8.5$ \\
\hline *Turbidity (NTU) & 3.43 & 3.24 & 4.26 & 7.86 & 5.0 \\
\hline $\begin{array}{l}* \text { Conductivity } \\
(\mu \mathrm{S} / \mathrm{cm})\end{array}$ & 537 & 646 & 415 & 301 & \\
\hline$*$ Temperature $\left({ }^{\circ} \mathrm{C}\right)$ & 25.2 & 25.5 & 25.7 & 25.1 & \\
\hline TDS & 820 & 780 & 720 & 680 & 1000 \\
\hline TS & 460 & 390 & 350 & 210 & 1000 \\
\hline \multicolumn{6}{|l|}{ TSS } \\
\hline Phosphate & 68 & 58 & 52 & 47 & $<50$ \\
\hline Sulphate & 360 & 340 & 290 & 260 & 400 \\
\hline Nitrate & 14 & 12 & 11 & 10 & 10 \\
\hline Lead & 0.40 & 0.35 & 0.38 & 0.24 & 0.05 \\
\hline Cadmium & 0.29 & 0.24 & 0.16 & 0.09 & 0.005 \\
\hline BOD & 5.10 & 5.90 & 6.10 & 6.40 & \\
\hline COD & 34 & 39 & 44 & 52 & \\
\hline Dissolved oxygen & 3.5 & 3.4 & 3.2 & 2.8 & \\
\hline$* \mathrm{FC}(\mathrm{CFU} / 100 \mathrm{ml})$ & 45 & 34 & 24 & 15 & 0 \\
\hline
\end{tabular}


Investigation of Water Quality and its Quotient Factor in Thiruppalai Village, Madurai, India.

\begin{tabular}{|l|l|l|l|l|l|}
$*$ *TC (CFU/100ml) & 102 & 94 & 76 & 54 & 0
\end{tabular}

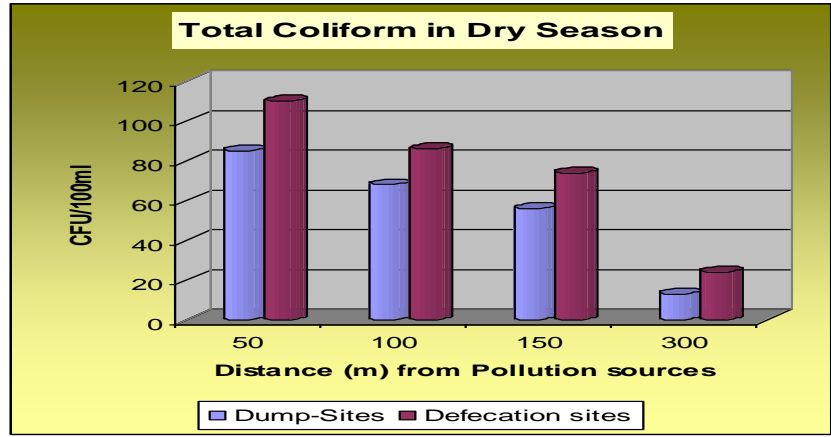

Figure 1: Decreasing total coliform count (CFU/100 ml) with increasing distance from pollution sources in dry season.

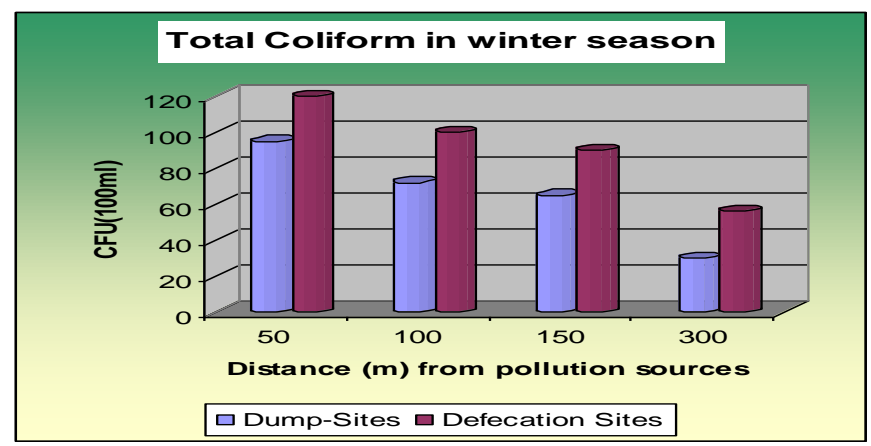

Figure 2: Decreasing total coliform count (CFU/100 ml) with increasing distance from pollution sources in winter season.

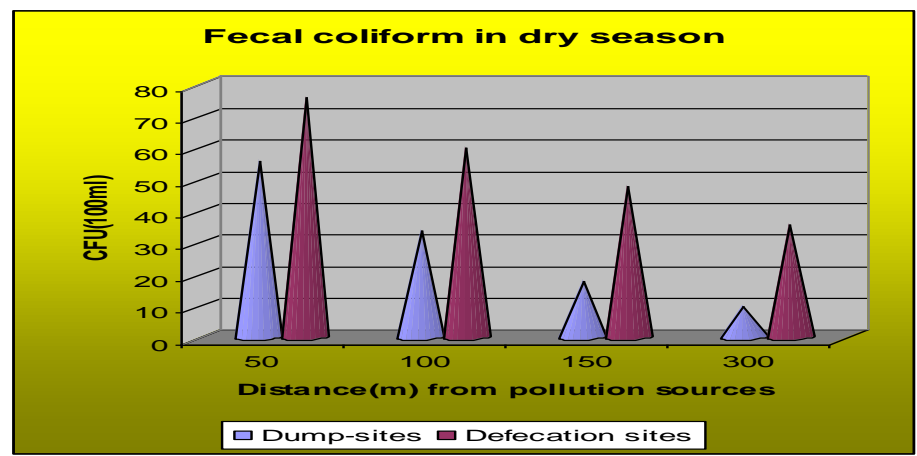

Figure 4: Decreasing fecal coliform count (CFU/100 ml) with increasing distance from pollution sources in dry season

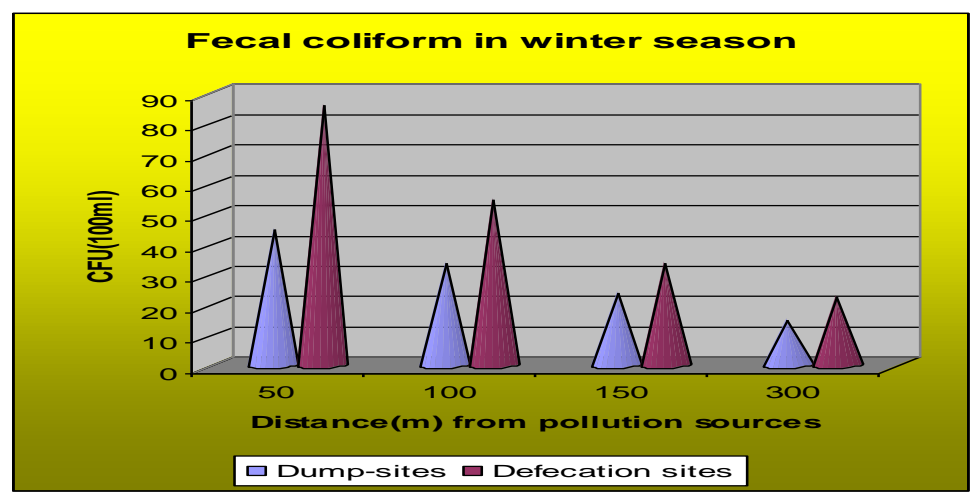

The increases were 30\%, 40\%,27\% , 48\%, 36\%, 56\% and 47\% in Electrical conductivity, BOD, COD, $\mathrm{TDS}, \mathrm{Cu}, \mathrm{Pb}$, fecal coliform and total coliform respectively during the rainy season when compare with the dry season. Similarly, the effect of distance from pollution sources also has determined the fecal and total coliform 
Investigation of Water Quality and its Quotient Factor in Thiruppalai Village, Madurai, India.

counts. The water quality parameters and the bacteria counts are more in the nearby pollution sites rather than far-off pollution sites (Table \& Fig.2). The increases were 36\%, 48\%,47\%, 38\%, 26\%, 66\% and 52\% in Electrical conductivity, $\mathrm{BOD}, \mathrm{COD}, \mathrm{TDS}, \mathrm{Cu}, \mathrm{Pb}$, fecal coliform and total coliform respectively during the rainy season when compare with the dry season. One way ANOVA test confirms a significant difference in parameters between rainy and dry season at 0.05 level of significance $(\mathrm{p}<0.05)$.

An analysis of conductivity, total solids and $\mathrm{PO}_{4}$ concentrations in the water samples near waste dumpsites and near defecation sites revealed that tested values were more higher in dumpsites than in defaecation sites during the dry season. This increase is $43 \%, 56 \%$ and $43 \%$ in conductivity, total solids and $\mathrm{PO}_{4}$ concentrations respectively in water samples nearing dumpsites when compare with water near defaecation sites. One way ANOVA test confirms a significant difference in parameters between sites at 0.05 level of significance $(\mathrm{p}<0.05)$.

The fecal and total coliform counts were more higher in the water samples near defecation sites than those water samples taken from 50 to $100 \mathrm{~m}$ well in wet season. The increase is $45 \%$ and $67 \%$ in fecal and total coliform counts in water samples taken near dumpsites in wet season over the samples collected in dry season. Further, this values were decreased by $23 \%$ and $34 \%$ in fecal and total coliform counts in water samples taken from 150 to $300 \mathrm{~m}$ of well in wet season over water samples taken in dry season. One way ANOVA test confirms a significant difference in parameters between the water samples collected at different depth of wells at 0.05 level of significance $(\mathrm{p}<0.05)$.

Similarly, the fecal and total coliform counts were higher in the water samples near defecation sites than those water samples near dump sites in wet season. The increase is $38 \%$ and $57 \%$ in fecal and total coliform counts in water samples taken near defecation sites over the samples collected from dumpsites in wet season. One way ANOVA test confirms a significant difference in parameters between sites in wet season at 0.05 level of significance $(\mathrm{p}<0.05)$. The Water quality quotient factor indicated in Figs $3 \& 4$ also revealed the influence of distance and season on water quality.

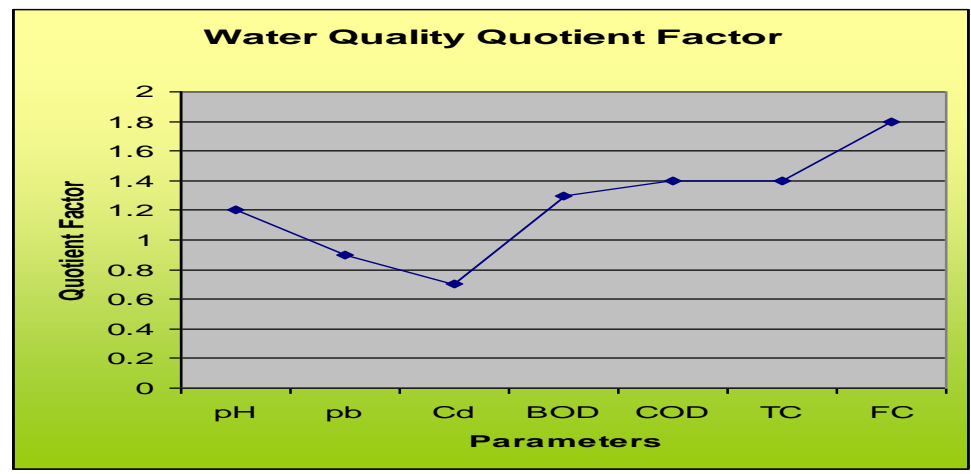

Fig.3: Quotient factors for water quality parameters in wells near dumpsite in dry seasons relative to winter seasons.

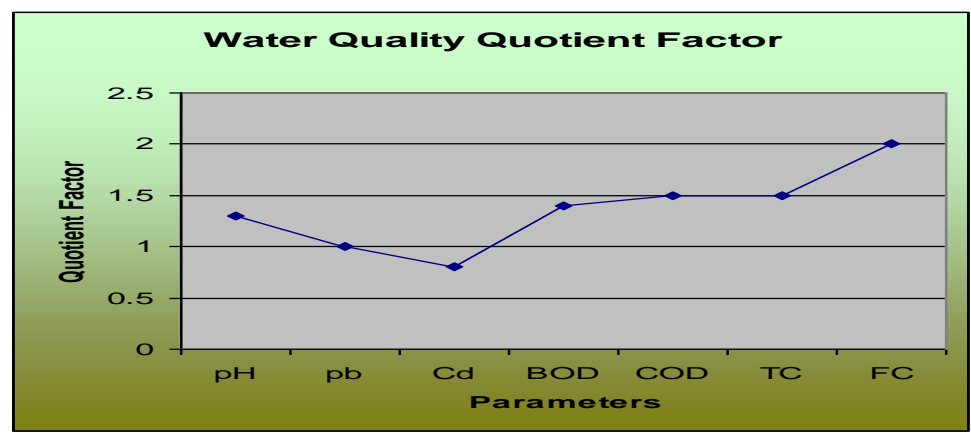

Fig.4: Quotient factors for water quality parameters in wells near Fecal sites in dry seasons relative to winter seasons.

\section{Discussion}

Results showed that the well water samples have good $\mathrm{pH}$ values in wells below $50 \mathrm{~m}$ from defecation sites (Burkart and Kalpin, 1993; Domogalski et al 2001). The high pH values for wells near to waste dump-sites in different seasons with quotient coefficients of 1.18 (dry season) and 1.14 (wet season) was attributed to the release of carbon dioxide, ammonia and methane during decomposition of the waste materials, that may 
percolate to the groundwater. Likewise, the low $\mathrm{pH}$ of water samples from wells near to defecation sites was attributed to sulphur and amino acid compounds from human and animal excreta. (Akanle et al 1985; Asubiojo et al 1985; Badmus et al 2001).

The conductivity levels of the water samples from wells near to dump-sites and defecation sites were $200 \mu \mathrm{S} / \mathrm{cm}$. This trend indicates the presence of $\mathrm{Pb}^{2+}, \mathrm{Cu}^{2+}$ and $\mathrm{Cd}^{2+}$ and $\left.\mathrm{SO}_{4}^{2-}, \mathrm{NO}_{3}^{-}, \mathrm{PO}_{4}{ }^{3-}\right)$ and solids and salts are in permissible limits, that favours the water for fishery and agricultural practices. Excess in sulphate above 600 ppm may create unfavorable condition for humans (Agbu, 1988; Adepelumi et al 2002).

This study exhibited that $\mathrm{Pb}, \mathrm{Cd}, \mathrm{FC}$ and $\mathrm{TC}$ have exceeded the guidelines of World Health Organization (WHO, 1998) for drinking water. The trend of increasing concentration in metal $(\mathrm{Pb})$ may be attributed to human interference (Root et al 1982, Wright 1985; Sangodoyin and Agbawhe, 1992; Edet, 1993; Sridhar 2000; Ikem et al 2002) such as open solid waste burning, quarrying (Groen et al 1988; Nikiladze and Mints, 1989; Malomo et al 1990; Obasi and Balogun, 2001). Increased soil metal burden from atmospheric deposit of air-borne particulates by wet precipitation and subsequent rainwater run-off of waste materials may enhance the metal concentration in water samples (Esry et al 1991). In addition, these metal levels may be increased owing to metal dissociation from rocks through that the water flows (Esa, 1983; Fecham et al 1986;).

Nitrate concentration above $10 \mathrm{ppm}$ may be dangerous to pregnant women and infants of three to six months age, because of its ability to develop methaemoglobinaemia or blue baby syndrome in the affected body (Aremu et al 2002). Traces of phosphates increase the tendency of troublesome algae to get grown in the water that in turn affect the oxygen level for fish (Esry and Habicht, 1986). The results also revealed that water quality with respect to about DO ( 3.0 to $5.06 \mathrm{mg} / \mathrm{L}$ ) is not suitable for drinking. COD and BOD are indices of organic pollution. High COD and BOD interfere with oxygen transfer to the soil, thus affecting plant growth (Esry et al 1991).

High coliform populations in all water samples are an indication of poor sanitary conditions in the village and this may be owing to unhygienic practices of public. (Onianwa et al 2001) that may be the sources for many diseases.

\section{Conclusions}

In conclusion, all pollutants were detected up to $150 \mathrm{~m}$ from wastes sites and the water quality is altered more in dry season than wet season. The water samples close to pollution source particularly dump-sites contained more $\mathrm{Pb}, \mathrm{Cd}$, and coliform levels (FC and TC) above the stipulated limits for potable water. The high coliform up to 40 in water samples near faecal sites relative to about dump-sites indicates that the groundwater resource is unfit for drinking and domestic uses.

It is recommended that water sources should be properly protected from the pollution sources and for which a strict measure should be taken by the government. Efficient solid waste management should be adopted to safeguard public health from water borne diseases. Also, the public should be given proper awareness about the need to have a perfect personal hygiene for a healthy life.

Acknowledgement: The authors acknowledge University Grants Commission, New Delhi for financing this work.

\section{References:}

[1.] Adediji, A, Ajibade L. T. 2005 Quality of well water in Ede area, southwest Nigeria. J. Hum. Ecology, $17(3), 223$-228.

[2.] Adekunle, A, Adekunle, A, Ndahi, N. P. 2003 SWM by combustion: Implication on the metal in the environment, Proceedings of $29^{\text {th }}$ WEDC International Conference, Abuja Nigeria, , p3- 5.

[3.] Adekunle, I. M, Arowolo, T. A, Ndahi, N. P, Bello, B, Owolabi, D. A. 2007. Chemical characteristics of humic acids in relation to lead, copper and cadmium levels in contaminated soils of southwest Nigeria, Annals of Environmental Science, North Eastern University, Boston, Massachusetts USA, 1, 23-34.

[4.] Adepelumi, A, Ako, B, Ajayi, I. T. 2002. Groundwater contamination in basement -complex area of Ile-Ife, southwestern Nigeria: A case study using the electrical-resistivity of geographical method. p.34.

[5.] Adesuyin, A. A, Aekeye, J. O, Umoh, J. U, Nadarajah, M. 1983: Studies on well water and possible health risks in Katsina, Nigeria. Journal of Hygiene, 90: $199-201$.

[6.] Agbu, A. A, Alaribe, H. C, Singh, K, Adesiyun,, A. A. 1988. Bacteriological studies and chemical analysis of public well water in Samaru and Zaria city in Northern Nigeria. Journal of Microbiology, 8(1-2): $88-98$.

[7.] Akujieze C. N, Coker, S. J, Oteze, G. E. 2003. Groundwater in Nigeria - a millennium experience - distribution, practice, problems and solutions. Hydrogeology Journal, 1: $259-274$

[8.] Alagbe, S. A. 2002. Groundwater resources of river Kan Gimi Baisn, north-central, Nigeria. Environmental Geology, 42 : 404 413 .

[9.] Amadi, P.A, Ofoegbu, C.O, Morrison, T. 1989. Hydrogeochemical assessment of groundwater quality in parts of the Niger Delta, Nigeria. Environmental Geology, 14 (3): 195 - 202.

[10.] American Public Health Association: 1998. Standard methods for the examination of water and wastewater, 20 ${ }^{\text {th }}$ edition, APHA, AWWWA, WEF, Washington DC.

[11.] Aremu, D. A, Olawuyi, J. F, Meshitsuka, S, Sridhar, M. K, Oluwande, P. A. 2002. Heavy metal analysis of groundwater from Warri, Nigeria. International Journal of Environmental Health Research, 12: 261-267.

[12.] Asubiojo, O. I, Nkono, N. A, Ogunsua, A. O, Oluwole, A. F, Wardi, N. I., Akanle, O. A, Spyrou, Ayers, R. A, Westcott, D. W. 1985. Water quality for Agriculture. FAO ID29 Rev 1. FAO Rome. 
[13.] Badmus, B. S. Odewande, A. A,Ojelabi, E. A,Oyedele, T. 2001. Leachate contamination effect on groundwater exploration. African Journal of Environmental Studies, 2(1): $38-41$.

[14.] Burkart, M. R, Kolpin. D. W. 1993. Hydrologic and land - use factors associated with herbicides and nitrate in near-surface aquifers. J. Environ. Qual, 22: 646-656.

[15.] Cruise J. F, Miller, R. L. 1994. Interpreting the water quality of Mayaguez Bay, Puerto Rico using remote sensing, hydrologic modeling and coral reef productivity. Proceedings of Second Thematic Conference on remote sensing for Marine and Coastal Environments, New Orleans, LA, pp. 193 -203.

[16.] Domagalski, J. K, Chao, L, Xinquan, Z. 2001. Comparative assessment of groundwater quality in the Tangshan region of the People's Republic of China and similar areas in the U.S. Scientific World Journal, 10(1) Suppl 2: $415-422$.

[17.] Edet, A. E. 1993. Groundwater quality assessment in parts of Eastern Niger Delta Nigeria, Environmental Geology, 22(1): 41-46.

[18.] Efe, S. I, Ogban, F. E, Horsfall, M Jr, Akporhnor, E. 2005. Seasonal variations of physico-chemical characteristics in water resources quality in western Niger Delta region, Nigeria, J. Applies Sci. Environ. Mgt., 9(1): 191-195.

[19.] Environment Canada: 1979. Analytical methods manual. Inland water Directorate, Water Quality branch, Ottawa, Canada, Part 1 5.

[20.] Esa, R. 1983. Drilled wells and groundwater in the Precambrian crystalline bedrock of Finland. Water Research Institute, Helsinki, Finland, No. 52, p57.

[21.] Esry, S. A, Habicht J. P. 1986. Epidemiologic evidence for health benefits from improved water and sanitation in developing countries. Epidemiologic reviews, 8: $117-128$.

[22.] Esry, S. A, Potash, J. B, Shiff, C. 1991. Effects of improved water supply and sanitation on ascariasis, diarrhea, Drancunculiasis, hookworm infection, schistosomiasis and trachoma. Bulletin of the World Health Organization, 6 (5): 609 - 621.

[23.] Fecham, R, Mcgarry M, Mara D. 1986. Water, Wastes and Health in Hot Climates, Wiley and Sons, New York, p. 82. Federal Ministry of Mines and Power (FMMP): 1974. Geological map of Nigeria, 1: 2, 000, 000 scales. Federal Ministry of Mines and Power, Nigeria.

[24.] Groen, J, Schumann, J. B, Gernaer, T. W. 1988. The occurrence of high nitrate concentration in groundwater in villages in Northwestern burkinafaso. J. Afri. Earth Sci, 7(7/8) : $999-1009$.

[25.] Ikem, A, Osibanjo, O, Sridhar, M. K. C, Sobande, A. 2002. Evaluation of groundwater quality characteristics near two waste sites in Ibadan and Lagos, Nigeria. Water, Air and Soil Pollution, 140 (1-4): 307-333.

[26.] Malomo, S, Okufarasin, V. A, Olorunnio, M. A, Omode, A. A. 1990. Groundwater chemistry of weathered zone aquifers of an area underlain by basement complex rocks. J. of African earth Sciences, 11: 357 -371.

[27.] Nikiladze, G, Mints, A. K, 1989. Water Treatment for Public and Industrial Supply. MIR Publishers, Moscow.

[28.] Obasi R. A, Balogun, O. 2001. Water quality and Environmental impact assessment of water resources in Nigeria. African Journal of Environmental Studies, 2(2): 228 - 231.

[29.] Onianwa, P. C, Jaiyeola, O. M, Egekenze R. N. 2001. Heavy metals contamination of topsoils in the vicinities of auto-repair workshops, gas stations and motor parks in a Nigeria city. Toxicol., and Environ. Chem, 84(1-4): 33 -39.

[30.] Punmia B. C. 1998. Jain A. K.: Wastewater Engineering. Laxmi Publications (P) Ltd, New Delhi.

[31.] Root J, Graveland A, Schultink L. J, 1982. Consideration of organic matter in drinking water treatment. Water Research, 16(1), $113-122$

[32.] Sangodiyin, A. Y. 1993.Considerations on contamination of groundwater by waste-disposal systems in Nigeria. Environmental Technology, 14: $957-964$.

[33.] Sangodoyin A. Y, Agbawhe O. M. 1992. Environmental study on surface and groundwater pollutants from abattoir effluents. Bioresource Technology, 41: 193 - 200.

[34.] Sridhar, M. K. C. 2000. Ground water in Nigerian urban centers: problems nd options. Schriftenr Ver Wasser Boden Luftyg, 105: 393-397.

[35.] Ugboaja A.N. 2004. Groundwater pollution near shallow waste dumps in southern Calabar, south-eastern Nigeria. Global Journal of Geological Sciences, 2(2), 199-206.

[36.] US Environmental Protection Agency: 2002. National recommended water quality criteria. Washington DC, US. Environmental Protection Agency Office of Water.

[37.] World Health Organization: 1998. Guidelines for drinking water quality, $2^{\text {nd }}$ edition, Geneva. Wright, J. B. 1985. Geology and Mineral Resources of West Africa. Allen \& Unwin, London. 